\title{
Environmental and Socioeconomic Impacts of Shrimp Farming in the Philippines: A Critical Analysis using PRISMA
}

\author{
Edison D. Macusi ${ }^{1,2}$, Darshel Ester P. Estor ${ }^{2}$, Elaine Q. Borazon ${ }^{3,}$, Misael B. Clapano ${ }^{1,2}$, Mudjiekeewis D. Santos $^{4}$ \\ 1 Institute of Agriculture and Life Sciences (IALS), Davao Oriental State University (DOrSU), Mati City, Da- \\ vao Oriental, Philippines \\ 2 Shrimp Vulnerability Assessment Project, Davao Oriental State University (DOrSU), Mati City, Davao Ori- \\ ental, Philippines \\ 3 International Graduate Program of Education and Human Development (IGPEHD), College of Social Sci- \\ ences, National Sun Yat-sen University, Kaohsiung, Taiwan \\ 4 National Fisheries Research Development Institute (NFRDI), Quezon City, Philippines \\ * Correspondence: Author: Elaine Q. Borazon <elaineqborazon@mail.nsysu.edu.tw>
}

\begin{abstract}
Shrimp aquaculture is under pressure to increase its production to meet the growing demand for food from a growing population. In the Philippines, aquaculture has experienced the shift from milkfish to prawn with its attractive marketable price. Its intensification has led to negative and positive impacts, which raised a range of environmental and socioeconomic problems. This paper reviewed the environmental and socioeconomic challenges that the shrimp aquaculture industry faced using the Preferred Reporting Items for Systematic Reviews and Meta-Analyses (PRISMA) method. We examined gaps and changes required to revitalize the industry. It examined and assessed the impacts of shrimp culture on the environment e.g. shrimp farm management, marine pollution, disease outbreaks, including the social, economic and climate change impacts. The presence of viral diseases such as White Spot Syndrome Virus (WSSV), Monodon Baculovirus (MBV), Infectious Hypodermal and Hematopoietic Necrosis Virus (IHHNV), Hepatopancreatic Parvovirus (HPV), and Yellow Head Virus (YHV), have caused approximate losses of 40,080 mt in 1997 to 51,000 mt in 2014 in the industry. Recommended strategies and policy changes were considered to improve shrimp aquaculture, including disease management, adopting good aquaculture practices, proper environmental monitoring, sustainable practices at the farm level and priorities for cooperation among concerned government agencies, local governments and involvement of state universities and colleges for better management practices.
\end{abstract}

Keywords: Aquaculture; environmental impacts; PRISMA; shrimp aquaculture; shrimp diseases; socioeconomic impacts

\section{Introduction}

Aquaculture serves the employment and food security needs of most Asian coastal countries, from Bangladesh, China, India, Indonesia, Philippines, Thailand and to Vietnam, are all aquaculture-reliant countries with large aquaculture sectors [3-7]. It is a major driver of socioeconomic development in poor rural and coastal communities, particularly in Asia, and is considered to relieve pressure and help maintain the sustainability of wild-caught species from rivers, lakes, and oceans as it provides for the shortfall of capture fisheries [8]. The rise of aquaculture has been one of the most profound changes in global food production over the past 100 years [9]. This industry has become a major source of food protein and is foreseen to support our seafood production as a sustainable alternative to wild-caught fish [5,10]. There is a prediction that the per-capita seafood consumption will continue to increase by $1.5 \mathrm{~kg}$ per year by 2025 [11]. Population growth and increased individual consumption indicate that farmed seafood products will be gradually more important as an additional food source, and aquaculture will play a vital role as natural fish stocks continue to decline [11,12]. 
Crustaceans contribute a significant portion of production and value among other aquatic species developed for aquaculture [13]. Penaeid shrimps are the most preferred crustaceans in aquaculture, as shown by its vast expansion of land area devoted to shrimp farming [14,15]. Globally, about 9.4 million metric tons $(\mathrm{mt})$ of farmed crustaceans were produced in 2020. Of this, 5.7 million mt were Penaeus vannamei (Pacific white shrimp) and Penaeus monodon (black tiger shrimp) production [1]. In most recent years it was the world's most valuable aquaculture species, increasing from less than 75,000 $\mathrm{mt}$ in 1980 to over 5.7 million $\mathrm{mt}$ in 2020 [1]. In the Philippines, shrimp production remains a valuable export commodity with total production in 2019 at 66,252 $\mathrm{mt}$, ranking fourth in value at U\$ 42.36 million, exported in Japan, South Korea, and the USA [2].

P. vannamei is one of the most popular shrimp species for culture [16]. This species became well-known for its desirable characteristics such as short culture-period and fast growth among tropical countries and made inroads in the global market [17]. Its production has grown tremendously in the past years due to its high economic return although it was also ravaged by diseases [18].

In the Philippines, shrimp production was mainly located in Negros and Panay Islands in Central and Western Visayas. Recently, this has changed, and shrimp production has been growing and increasing in other areas, such as in Central Luzon, other parts of Central Visayas, SOCCSKSARGEN, Northern Mindanao, Caraga and Davao regions $[4,14,19,20]$. Thus, P. vannamei production has spread in various parts of the country whether cultured alone or in combination with other finfish species $[8,21]$. There are new cultivation techniques applied and new cultivation areas that were previously non-existent, which means farmers were encouraged to adapt because of high economic returns $[17,22]$. Despite what happened to the P. monodon crises in the mid-and-late 1990s, shrimp farmers and investors have high hopes and expectations for better market demand in local and overseas markets $[17,19,23,24]$.

Before the importation of $P$. vannamei, $P$. monodon was the only species being exported abroad [17]. P. monodon is indigenous to the Philippines and can be grown in freshwater, brackish water, and marine water [24] throughout northern Luzon to the southernmost parts of Mindanao [17]. During the continuous growth and expansion of shrimp culture in the Philippines, the shrimp industry reached its highest peak in 1992 when it produced about 120,000 $\mathrm{mt}$ [25].

Below is the development history of the shrimp industry in the Philippines (Table 1). Based on this, beyond the year 2000 showed the lack of a clear industry roadmap for reinvigorating the shrimp industry in the Philippines despite the availability of all relevant technologies to expand and to increase its existing capacity. While Republic Act 8550, otherwise known as the Philippine Fisheries Code of 1998, was enacted to law, it vaguely contained references on incentivizing the fisheries and the aquaculture industry. For instance, in section two (2) objective three (3), it states, the "Improvement of productivity of aquaculture within ecological limits". This law only states increasing the aquaculture production but does not specify how to protect the ecosystem for example the mangrove ecosystem during forest clearing, pond construction and release of waste water in the case of milkfish and shrimp production. It also does not state nor specify whether the state can solely decide the terms for putting up ecological limits based on the best available scientific expertise. Even the more specific provisions contained in article three (3), section eight (8) of the same law which provides for incentives and disincentives of proper cultivation or culture of species, do not properly discuss the process to attain the proper method of culturing species in all stages such that it reduces possible environmental impacts. Further, in the implementing rules and regulation of RA 8550, the act of reforestation of bays, shores and dikes and building of structures to minimize water pollution by the fishpond lessee are all stated (rule 46.2), including good aquaculture practices (rule 47.1) that would be crafted by the Bureau of Fisheries and Aquatic Resources (BFAR) was also specified. Yet a cursory visit to fishpond farms (small-scale and commercial operators) show that these are not being followed most of the time or shrimp farmers are minimally fulfilling these guidelines of the law. Despite these failures to adopt sustainability practices except 
for compliance certifications when exporting shrimps and finfish to premium markets such as Europe, Japan and the USA which require adherence to traceability and other food safety rules and protocols, the required compliance certificates become external motivating factors to access those premium markets.

In this study, we used Preferred Reporting Items for Systematic Reviews and MetaAnalyses (PRISMA) which is a published approach that helps in facilitating a processoriented flow for the researchers to broadly evaluate and review resources [35] and had been utilized by researchers [36-39]. The PRISMA approach requires four stages: (1) identification; (2) screening; (3) eligibility assessment; and (4) inclusion. This paper reviews the possible environmental and socioeconomic impacts, challenges, and disease outbreaks that affected the Philippines shrimp industry over the years and examined gaps and possible strategies required to revitalize the industry for future resilience.

Table 1. Milestones of Shrimp Industry in the Philippines.

\begin{tabular}{|c|c|c|}
\hline Year & Milestone & References \\
\hline 1960s & $\begin{array}{l}\text { - The Philippines was one of the pioneers in shrimp farming } \\
\text { - } \quad \text { Extensive method of production was introduced } \\
\text { - } \quad \text { Shrimp farming was dependent on fries collected from the wild } \\
\text { - } \quad \text { Annual production is far below } 5,000 \mathrm{mt}\end{array}$ & {$[17,24]$} \\
\hline 1970s & $\begin{array}{ll}\text { - } & \text { The first culture systems were extensive } \\
\text { - } & \text { Penaeus monodon became popular in Japan } \\
\text { Export of first trial shipment to Japan } \\
\end{array}$ & {$[17,24]$} \\
\hline $1980 \mathrm{~s}$ & 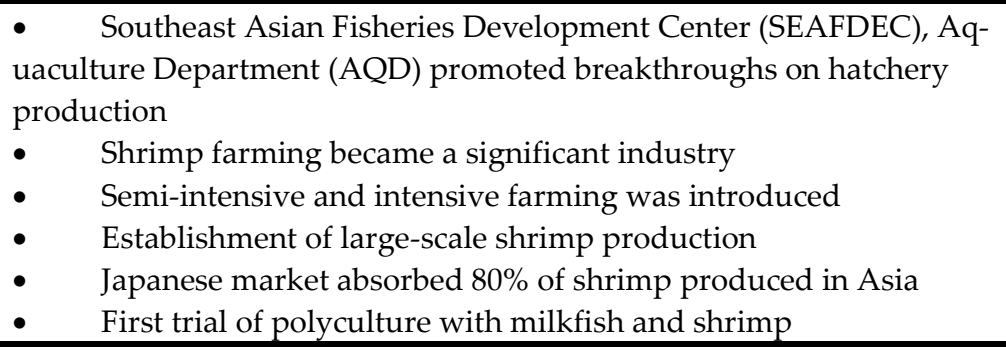 & {$[17,26,27]$} \\
\hline 1990s & $\begin{array}{l}\text { - } \quad \text { Japanese market collapsed } \\
\text { - } \quad \text { Rapid increase in production due to expansion of pond areas } \\
\text { - } \quad \text { Government support and financing no longer a problem } \\
\text { - } \quad \text { The "boom and bust" period } \\
\text { - } \quad \text { Industry peak production and decline due to disease outbreak } \\
\text { - }\end{array}$ & {$[17,23,24,28]$} \\
\hline $2000 \mathrm{~s}$ & $\begin{array}{l}\text { - Verification runs on environment-friendly shrimp culture con- } \\
\text { ducted by SEAFDEC AQD } \\
\text { - } \quad \text { SEAFDEC AQD started to respond to the requests of private sec- } \\
\text { tors for on-farm techno-transfer demo } \\
\text { - Shrimp production increased from } 34,627 \mathrm{mt} \text { in } 1999 \text { to } 42,390 \\
\text { mt in } 2001\end{array}$ & {$[17,29]$} \\
\hline & - $\quad$ First investigations on biocontrol of shrimp diseases & \\
\hline $2010 s$ & $\begin{array}{l}\text { - } \quad \text { Current production hit } 60,000 \mathrm{mt} \text { in } 2019 \\
\text { - } \quad \text { Exports of shrimp in South Korea, Japan and the USA } \\
\text { - } \quad \text { Inadequate supply of shrimp fries still an issue } \\
\text { - } \quad \text { Sustainable production using IMTA (Integrated Multi-Trophic } \\
\text { Aquaculture), polyculture and greenwater technology have been } \\
\text { tested }\end{array}$ & {$[2,21,22,34]$} \\
\hline
\end{tabular}

\section{Materials and Method}

This paper applied the Preferred Reporting Items for Systematic Reviews and MetaAnalyses (PRISMA) to review the interaction between shrimp farming and the natural environment, assess the impacts of shrimp farming, and suggest solutions for gaps that the government may need to fill-up. The systematic review was carried out using the 
scheme presented in Figure 1. The literature search encompassed the period between 1990 to 2021. Inclusion criteria were based on the ISI/SCOPUS publication in WOS (Web of Science) and SCOPUS databases. Records were first identified through data searching followed by the removal of duplicates. Next, screening and data extraction were performed, which means removing articles that did not meet the eligibility criteria. The eligibility criteria required evaluating the remaining articles if they were related to the subject of interest by browsing its abstract or content. The last step was selecting studies included in the review based on articles that passed the eligibility assessment [35]. The search for papers to be included in this review made use of key terms such as, "shrimp farming in the Philippines", "environmental and socioeconomic impacts", "climate change impacts on shrimp fisheries", "viral diseases on shrimps" and papers published by authors on the Philippines shrimp fisheries.

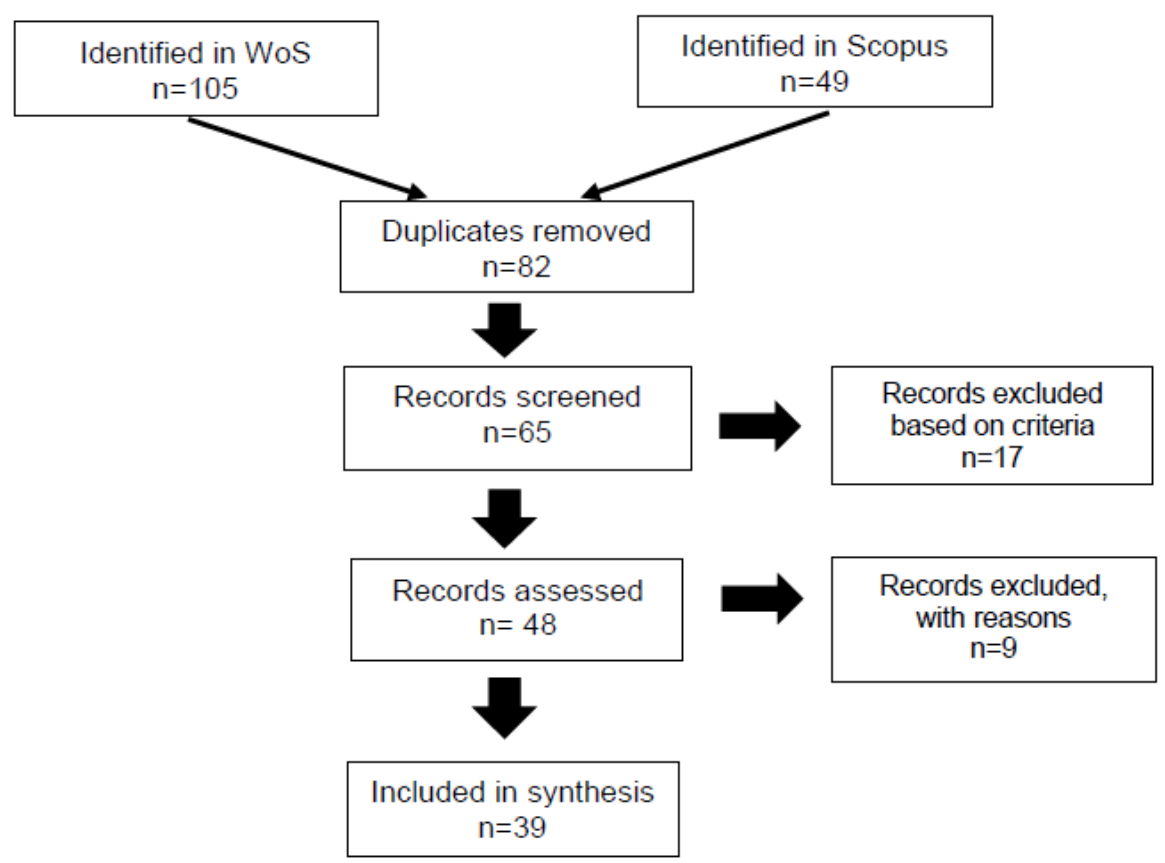

Figure 1. Flow of information through the different phases of a systematic review (adapted from Moher et al., 2009).

All the papers included were then identified from the Web of Science (WoS) and Scopus databases of the literature that were downloaded. These two databases were chosen because of their comprehensive and quality publications that they host and curate. This means that we excluded reports especially those coming from agencies such as DENR (Department of Environment and Natural Resources), DA (Department of Agriculture), BFAR (Bureau of Fisheries and Aquatic Resources) and SEAFDEC (Southeast Asian Fisheries Development Center) that were unpublished and not found in the two databases. We still think that this will not have an impact on the generated insights provided by this method. For this investigation, we limited our coverage to studies on Philippine shrimp aquaculture from 1990 to 2021 and considered only full-text journal articles in English mainly because there are almost three decades since the time that shrimp production hit its highest peak then declined and continues to keep pace with what is environmentally acceptable and sustainable culture practices.

A VOSviewer bibliometric analysis [40] was then conducted to visualize the co-occurrence of author's keywords and index and to analyze textual data (title and abstract). 
Co-occurrence analysis allows one to identify the most frequently used and highly networked term. A qualitative thematic analysis of the selected literature $(n=39)$ followed through a synthesis approach utilizing narratives and summaries [41-42].

\section{Results and Discussion}

Found below are Figures 2 and 3 which showed the co-occurrence map based on keywords and text data from the various study abstracts and titles from 1990 to 2021. A total of 120 authors and index keywords were identified and a filtering of keywords had been carried to visualize the most relevant ones. Table 2 presents the occurrence classification by author and index keywords. The keyword 'shrimp culture' takes the first position in terms of total link strength and occurrences, followed by Philippines, decapoda, shrimp farming, and aquaculture. The cluster analysis of the author/index keywords shows that the most commonly-used keywords (Figure 2) are clustered into three: cluster one (in red color) were aquaculture, socioeconomic effects, ecological effects, pollution, Penaeus monodon, mangroves; cluster two (in green color) were fishery production, Philippines, and decapoda; and cluster three (in blue color) were shrimp farming/culture, and economics.

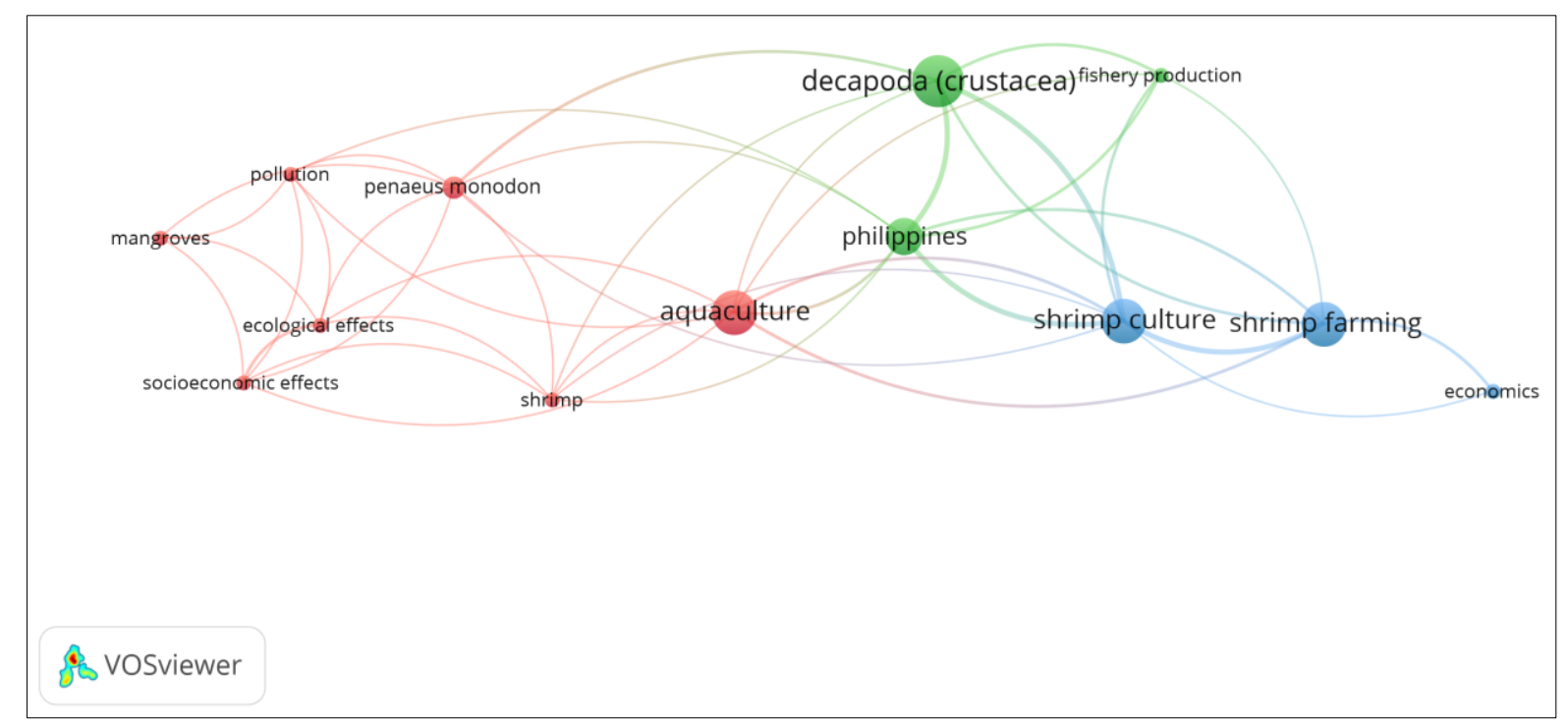

Figure 2. Co-occurrence map based on keywords.

Table 2. Occurrence classification by author/index keywords

\begin{tabular}{lrrr}
\hline Keywords & Occurrences & Links & Total link strength \\
\hline Cluster 1 & 6 & 9 & \\
Aquaculture & 2 & 6 & 12 \\
Ecological effects & 2 & 4 & 7 \\
Mangroves & 3 & 8 & 4 \\
Penaeus monodon & 2 & 6 & 9 \\
Pollution & 2 & 7 & 6 \\
Shrimp & 2 & 6 & 7 \\
Socioeconomic effects & & & 7 \\
Cluster 2 & 7 & 7 & 16 \\
Decapoda(crustacean) & 2 & 5 & 8 \\
Fishery production & &
\end{tabular}


Philippines

\section{Cluster 3}

Economics

Shrimp culture

Shrimp farming
5

2

6

6
8

17

Source: own elaboration

The most common words from the text data (Figure 3) were also categorized into three clusters: cluster one (in red color) were farm, practice, use, access, seaweed, fish, milkfish; cluster two (in green color) were shrimp farming, development, area, service, enforcement; and cluster three (in blue color) were input, industry, difference, and feed. Terms in larger circles (i.e. aquaculture, Philippines, decapoda) indicate higher number of publications in which these occur together. Cluster in the same color suggests a similar topic among the publications. Table 3 presents the classification by occurrence of most commonly used terms from the abstract. In terms of the number of occurrences, 'shrimp farming' and 'area' takes the first position while 'area' has the highest link strength followed by shrimp farming.

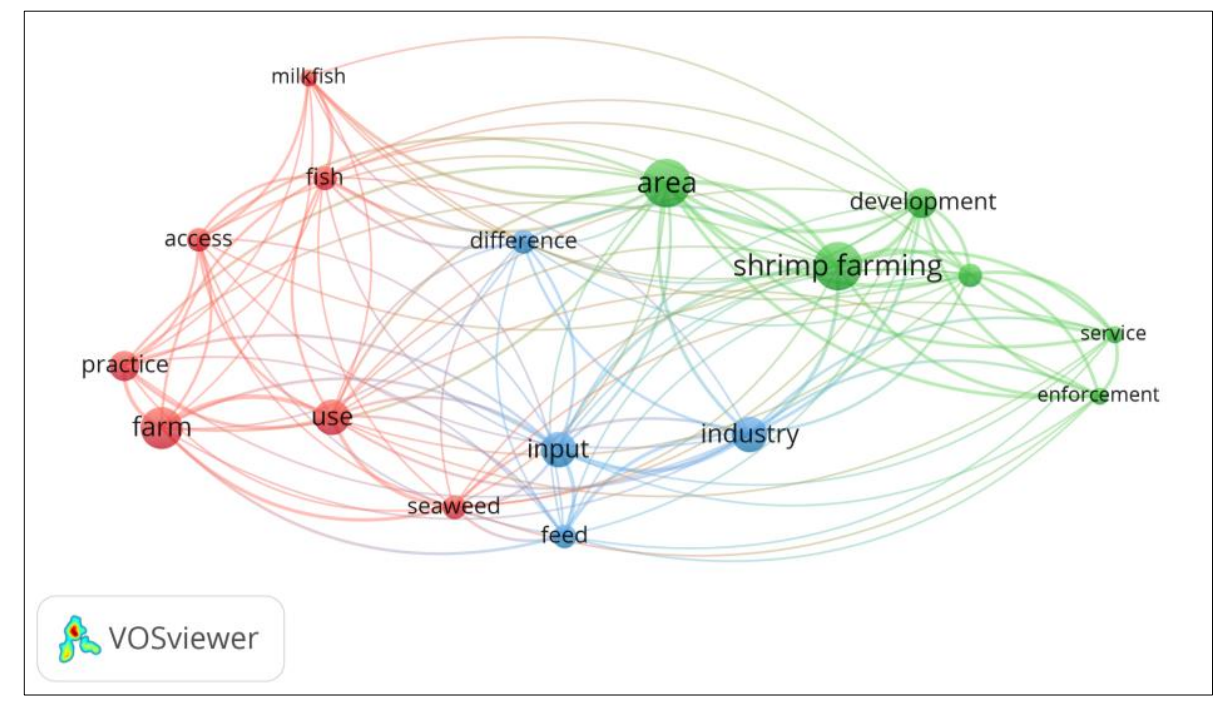

Figure 3. Co-occurrence map based on text data.

Table 3. Occurrence classification of texts from abstract

\begin{tabular}{lcrr}
\hline Abstract & Occurrences & Links & Total link strength \\
\hline Cluster 1 & 4 & & \\
Access & 7 & 12 & 18 \\
Farm & 4 & 11 & 25 \\
Fish & 3 & 14 & 22 \\
Milkfish & & 10 & 15
\end{tabular}




$\begin{array}{llll}\text { Practice } & 5 & 11 & 19 \\ \text { Seaweed } & 4 & 15 & 23 \\ \text { Use } & 6 & 16 & 31\end{array}$

Cluster 2

\begin{tabular}{llll} 
Area & 8 & 16 & 41 \\
Development & 5 & 14 & 29 \\
Enforcement & 3 & 10 & 21 \\
Mangrove & 4 & 13 & 25 \\
Service & 3 & 10 & 21 \\
Shrimp farming & 8 & 15 & 35 \\
Cluster 3 & & & \\
Difference & 4 & 12 & 16 \\
Feed & 4 & 15 & 23 \\
Industry & 6 & 15 & 23 \\
Input & 6 & 15 & 29 \\
\hline
\end{tabular}

Source: own elaborations

Moreover, Figures 4 and 5 present an overlay visualization of the frequently used terms from 1990 to 2021, thus showing the recent study trends on shrimp farming in the Philippines. The recent years have focused on pollution, access, and practices.

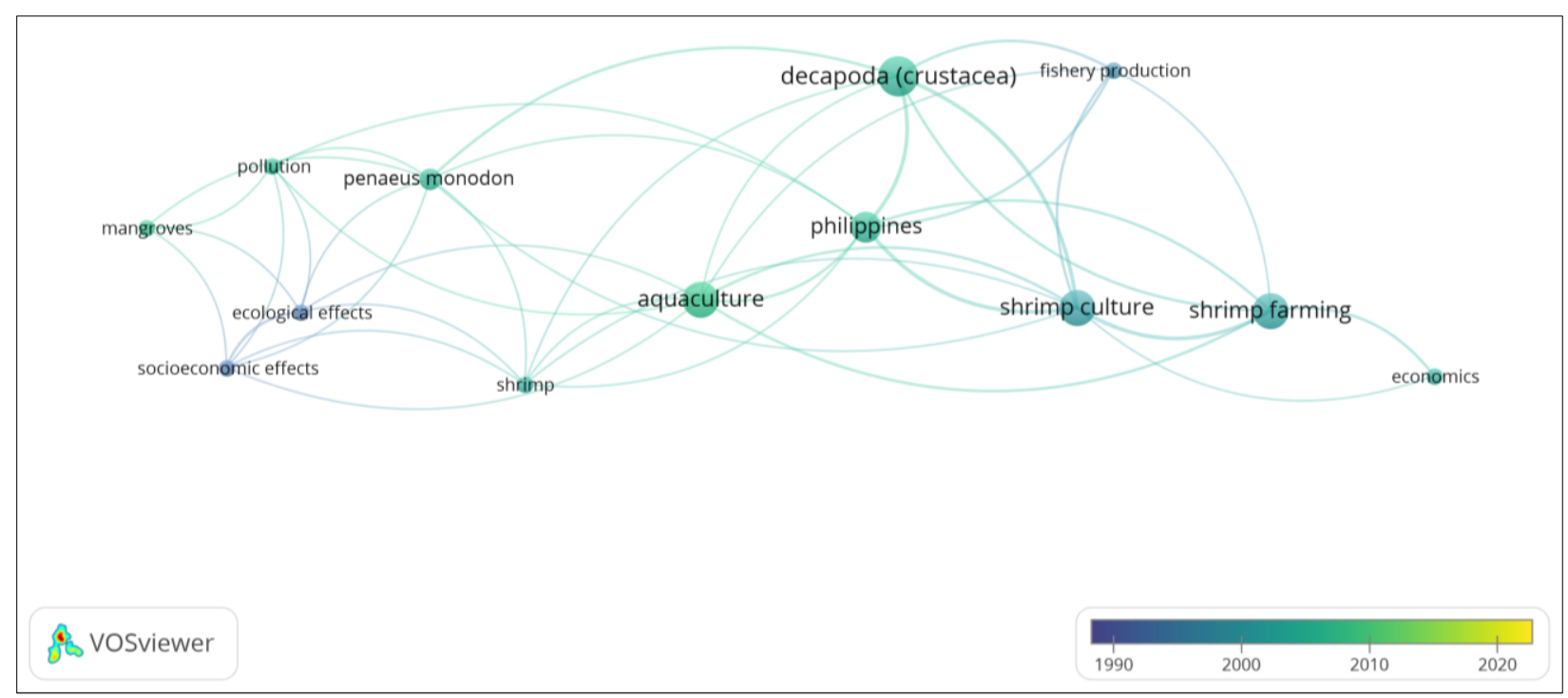

Figure 4. Overlay visualization of most frequently-used terms. 


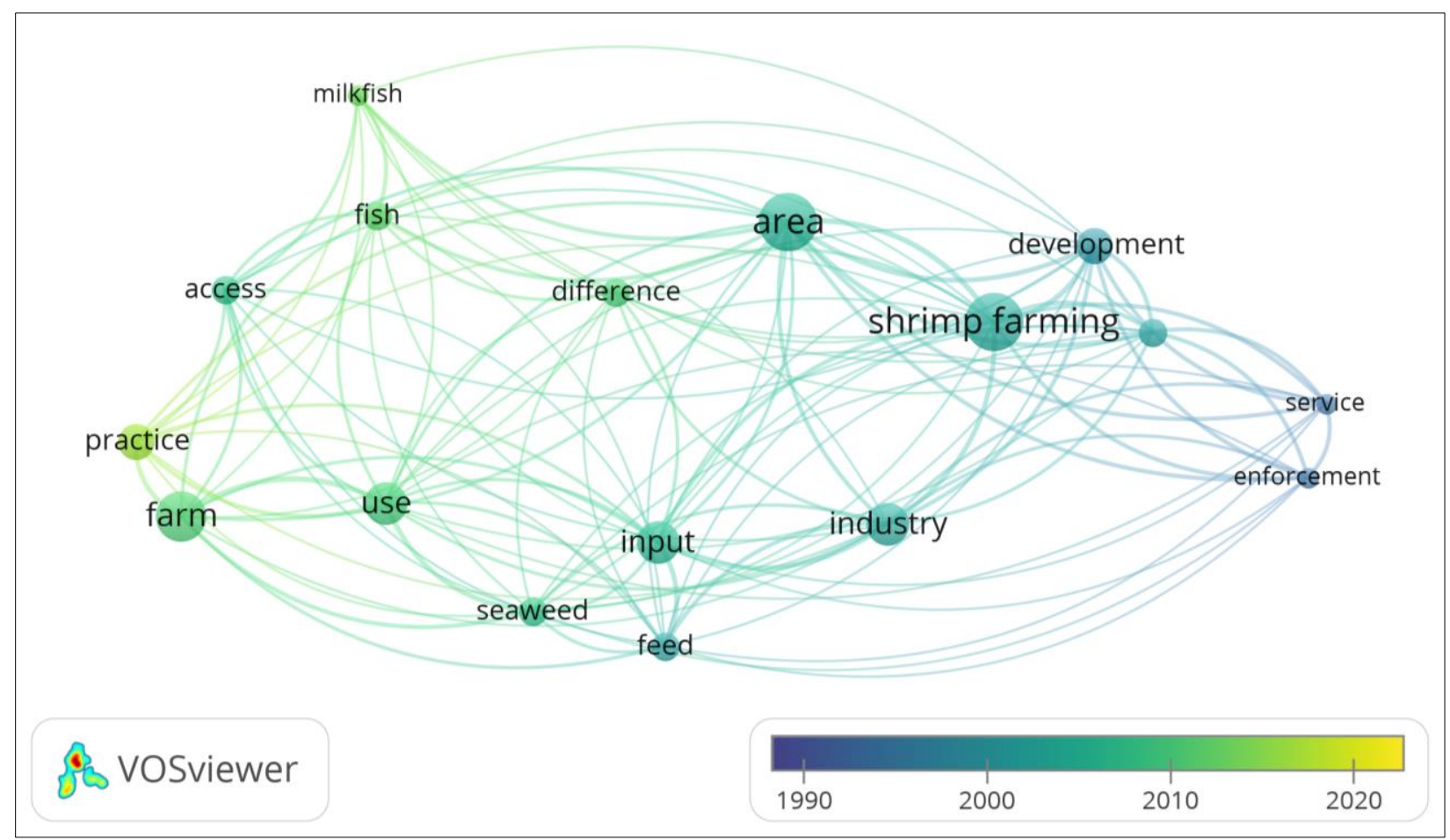

Figure 5. Overlay visualization of most frequently-used terms.

Presented in Table 4 were studies conducted in the year 2007 (18\%) and in 2011 (10\%) which reflect predominant publications that came out during that time with studies conducted in the fisheries and aquaculture sectors specifically related to environmental impacts and socioeconomic studies.

Table 4. Literature profile by year of publication.

\begin{tabular}{|c|c|c|c|}
\hline Year & No. of Studies & $\%$ & Journal Name \\
\hline 1993 & 1 & 2.56 & \\
\hline 1995 & 2 & 5.13 & \\
\hline 1997 & 2 & 5.13 & \\
\hline 1998 & 2 & 5.13 & \\
\hline 1999 & 1 & 2.56 & \\
\hline 2000 & 1 & 2.56 & \\
\hline 2001 & 2 & 5.13 & \\
\hline 2002 & 1 & 2.56 & Philippine Journal of Science \\
\hline 2003 & 2 & 5.13 & Philippine Agricultural Scientist \\
\hline 2004 & 1 & 2.56 & Fisheries Science \\
\hline 2005 & 1 & 2.56 & Estuarine Coastal and Shelf Science \\
\hline 2006 & 1 & 2.56 & Journal of General and Applied Microbiology \\
\hline 2007 & 7 & 17.95 & Aquaculture Research \\
\hline 2008 & 2 & 5.13 & Journal of Social, Political, And Economic Studies \\
\hline 2009 & 1 & 2.56 & Diseases of Aquatic Organisms \\
\hline 2011 & 4 & 10.26 & Bulletin of Marine Science \\
\hline 2012 & 1 & 2.56 & Environmental Management \\
\hline 2014 & 1 & 2.56 & Fish Pathology \\
\hline 2015 & 1 & 2.56 & Hydrobiologia \\
\hline 2017 & 1 & 2.56 & Journal of General and Applied Microbiology \\
\hline 2018 & 1 & 2.56 & \\
\hline 2020 & 1 & 2.56 & \\
\hline 2021 & 2 & 5.13 & \\
\hline Total & 39 & 100.00 & \\
\hline
\end{tabular}


Among the papers reviewed using the method of identifying, analyzing and reporting patterns (themes) within the data, these were categorized into five broad categories based on their keywords, title, and frequently used terms: farm management (12 studies or $31 \%$ ), diseases (9 studies or $23 \%$ ), marine pollution ( 8 studies or $21 \%$ ), socioeconomic impacts ( 8 studies or $21 \%$ ), and climate change ( 2 studies or $5 \%$ ) as shown in Table 5 . These broad categorizations also conform with the earlier clustering of keywords and text data mainly related to marine pollution or ecological impacts, socioeconomic impacts, shrimp farming and practices, development and inputs and fishery production.

Table 5. Literature categorized according to the Keywords.

\begin{tabular}{ccc}
\hline Themes & No. of Studies & \% \\
\hline Farm Management & 12 & 30.77 \\
Disease & 9 & 23.08 \\
Marine Pollution & 8 & 20.51 \\
Socio-economic impacts & 8 & 20.51 \\
Climate Change & 2 & 5.13 \\
Total & $\mathbf{3 9}$ & $\mathbf{1 0 0 . 0 0}$ \\
\hline
\end{tabular}

Impact assessment has been pointed out in several studies to be essential for better management to be identified and reduce disease and pollution impacts for the industry [43]. Moreover, the major issues of shrimp farming included the loss of important ecological and socioeconomic functions of mangrove ecosystems [23,44] and impacts of climate change to the fisheries sector leading to possible economic effects in the long term $[45,46]$. These themes were discussed as follows:

\subsection{Farm management}

Awareness about the need to reduce the impacts of shrimp farming has been a global issue. The major issues of shrimp farming include the loss of important ecological and socioeconomic functions of mangrove ecosystems [42]. Farm and health management practices focusing on disease prevention rather than treatment, maintenance of hygiene and biosecurity measures, and the responsible and effective use of chemicals could be the key to the sustainability of aquaculture [47].

\subsection{Disease}

From the studies reviewed, the presence of viral diseases such as White Spot Syndrome Virus (WSSV), Monodon Baculovirus (MBV), Infectious Hypodermal and Hematopoietic Necrosis Virus (IHHNV), Hepatopancreatic Parvovirus (HPV) and Yellow Head Virus (YHV) has been identified in several provinces in the Philippines (Table 6). They have now occurred in Pampanga, Bataan, Batangas, Bulacan, Camarines Norte and Mindoro Oriental and Palawan in Luzon; Capiz, Bohol, and Negros Oriental in Visayas; General Santos and Sarangani Province in Mindanao [48,49]. In the 1980s, the intensive monoculture of Penaeus monodon, commonly known as black tiger shrimp, was introduced and gained wide acceptance in the Philippines. Later, this shrimp species was affected by infectious diseases which caused its aquaculture and economic decline. In the Philippines, intensive shrimp farmers have reduced their culture runs due to viral and bacterial disease outbreaks [48,49]. Diseases of penaeid shrimps may be caused by living agents like bacteria, fungi, parasites, and viruses and non-living factors such as nutritional deficiencies, toxic substances, and environmental problems. Penaeus monodon, Penaeus merguiensis, and Penaeus indicus were major species cultivated in the Philippines affected by diseases [50]. Diseases are the topmost issues and challenges in shrimp aquaculture worldwide $[9,18]$. According to Andrino-Felarca et al., (2015), the major viral pathogens affecting the Philippines shrimp industry include White Spot Syndrome Virus (WSSV), Monodon Baculovirus (MBV), Infectious Hypodermal and Hematopoietic Necrosis Virus (IHHNV), Hepatopancreatic Parvovirus (HPV), Yellow Head Virus (YHV), and Taura Syndrome Virus (TSV). The principal host for TSV is the Penaeus vannamei and the Penaeus stylirostris. 
However, the outbreak of virus diseases such as the White Spot Syndrome Virus (WSSV) in the early 1990s resulted in a significant decline in shrimp production in Asia [18,50]. On further investigation, WSSV was found to have originated from Chinese hatcheries, where infected hatchery-produced Penaeus japonicus were imported to Japan in 1993 [19,52], and which later spread to other countries such as the Philippines [53]. There were also other widespread diseases such as vibriosis and luminous bacterial (Lumbac) infections. It had the same impact as the WSSV which contributed to a significant economic loss among shrimp growers $[17,54]$. Due to the WSSV pandemic, the Philippine government decided to ban the importation of live shrimp except for scientific or educational purposes following required permission. This is to prevent the spread of the diseases [16]. Technically $P$. vannamei was first introduced in the Philippines in 1978 but the production was unsuccessful. Since there was a prohibition on importing live shrimp, the private sector illegally imported P. vannamei labeled as milkfish fry from Taiwan in 1997. Later in 2001, because of this incidence, the government also prohibited the culture of this shrimp species with corresponding penalties [55]. Despite this early setback in the culture of $P$. vannamei in the Philippines, by 2006, the Philippines has become one of the main producer countries of $P$. vannamei based on FAO Fishery Statistic in 2006. The illegal shipments of the shrimp remain uncontrolled, and possibilities of contamination of TSV remains [56]. The viral disease appears to be more widespread during the dry season than during the wet. The presence of TSV had also been detected in P. monodon adults. This disease has increased social impacts associated with shrimp farming, including poverty and landlessness, food insecurity, and impacts on the health and education of shrimp farmers and their families. One of the main issues in the recent expansion of shrimp culture is social conflict with other resource users. This usually happens when coastal lands are leased or bought for the use of large multinational companies or export led companies for cultivating various aquaculture species such as milkfish or shrimp. Coastal communities are then displaced, including their markets and livelihoods are gone. In other cases, the process of pond construction and maintenance, the former occupants of the cultivated area are given priorities during the hiring of workers. Nonetheless, world wide shrimp aquaculture production has been depressed by disease, particularly caused by luminous vibrio and/or viruses $[18,56,66]$.

Table 6. Common diseases and their effects on the various life stages of shrimp.

\begin{tabular}{|c|c|c|c|}
\hline Disease & Effects & Stage of Culture & References \\
\hline $\begin{array}{l}\text { White Spot Syndrome Virus } \\
\text { (WSSV) }\end{array}$ & $\begin{array}{l}\text { First described from Japan where ini- } \\
\text { tial outbreak occurred in Penaeus japon- } \\
\text { icus in 1993. Develops rapidly and } \\
\text { reaches } 100 \% \text { mortality within 3-10 } \\
\text { days, the white inclusion evidently } \\
\text { represents abnormal deposits of cal- } \\
\text { cium salt }\end{array}$ & $\begin{array}{l}\text { All larval stages of Penaeus mono- } \\
\text { don }\end{array}$ & [58-60] \\
\hline $\begin{array}{l}\text { Hepatopancreatic Parvo Virus } \\
\text { (HPV) }\end{array}$ & $\begin{array}{l}\text { The hepatopancreas of affected shrimp } \\
\text { cause abnormal metabolism and even- } \\
\text { tual death; Mortalities may reach } 50 \% \\
\text { within } 4-8 \text { weeks }\end{array}$ & $\begin{array}{l}\text { Juveniles and adults of } P . \text { monodon } \\
\text { and } P \text {. merguiensis }\end{array}$ & [61] \\
\hline Taura Syndrome Virus (TSV) & $\begin{array}{l}\text { First recognized in shrimp farms in Ec- } \\
\text { uador in } 1992 \text { and caused catastrophic } \\
\text { losses with a very high cumulative } \\
\text { mortality rate of affected } P \text {. vannamei; } \\
\text { Includes reddening of the tail fan and } \\
\text { visible necrosis in the cuticle. }\end{array}$ & Post-larvae and broodstocks & {$[28,56,62,63]$} \\
\hline $\begin{array}{l}\text { Infectious Hypodermal and Hem- } \\
\text { atopoietic Necrosis Virus (IH- } \\
\text { HNV) }\end{array}$ & $\begin{array}{l}\text { First reported in Hawaii in 1980, the } \\
\text { presence of the virus can cause death } \\
\text { of the cell of the cuticle, blood-forming } \\
\text { tissues, and connective tissues which }\end{array}$ & All life stages of $P$. monodon & {$[61,62]$} \\
\hline
\end{tabular}


cause abnormal metabolism that leads

to mortalities of the shrimp.

Appearance of brownish to black

Shell Disease erosin of the carapace, abnominal seg ment, tail, gills and appendages. The affected shrimp appendages show a All life stages of $P$. monodon, $P$. merguiensis and $P$. indicus cigarette butt-like appearance.

Also first reported in Hawaii in 1980, viral occurrences affect cell nuclei from Infectious Myonecrosis Virus subcuticular epithelium of the mouth (IMNV) subcuticular epithelium of the mouth
appendage, gill, thoracic ganglion, and nerve fiber of the walking leg, but can also occur sparsely in the cytoplasm.

Larval shrimp are less prone to infestation than post-larval, juvenile and adult stages due to the rapid succession of molts throughout the different Filamentous Bacterial Disease larval stages while infected eggs show a thick mat of filaments on the surface All life stages of $P$. monodon, $P$. merguiensis and $P$. indicus which may affect the respiration or hatching.

\author{
The affected shrimp exhibits pale blu- \\ ish-gray to dark and dark blue-black \\ coloration that cause sluggish and in- \\ active swimming movements, loss of All life stages of Penaeus monodon \\ appetite, and retarded growth. The \\ presence of virus damages the organ \\ that weaken the shrimp and lead to \\ gradual mortalities \\ One of the major diseases in grow-out \\ cultured shrimps weakens the larvae \\ and juveniles of the infected shrimp. \\ The larvae become opaque-white whilePost larval stage and broodstock \\ the juveniles have discolored portions \\ on the body. Systemic infection reaches \\ to $100 \%$ of the affected population.
}

Luminous Vibriosis

\title{
3.3. Marine Pollution
}

More than 100 chemicals and biological products are used in aquaculture from pond preparation to culture period and for disease prevention and control in the Philippines (Table 7)[47]. The practice of polyculture and extensive farming did not pose any major problems, however, when farm methods shifted to semi-intensive and intensive system, high stocking density and formulated feeds were used. The culture intensification has resulted in making shrimps susceptible to several infectious diseases, and consequently, the use of chemical and biological products became certain to prevent and treat these diseases [45]. Water management became difficult as a result of culture intensification leading to uncontrolled feed wastes, and release of effluents to the marine environment affected the diversity of phytoplankton, spawning grounds, nursery habitats as well as seagrass and mangrove ecosystems [19]. The use of feeds and the continued release of effluents in nearby waters causes water quality deterioration in ponds and receiving water overtime as total nitrogen $(\mathrm{N})$ and phosphorus $(\mathrm{P})$, nitrite, silicate, orthophosphate, dissolved oxygen, and biological oxygen demand increases, the water visibility also decreases in intensive culture which often leads to cases of massive fish kills and economic losses in the industry $[19,29,30,31]$. This was mainly because of high nutrient deposits in the sediment and water column from fish feed wastes, which can trigger algal blooms that affect shellfishes and may pose a threat to mariculture activities such as farms of milkfish 
(Chanos chanos), and tilapia (Oreochromis niloticus) [30,31]. For instance, various factors have been implicated in the occurrence of fish kills in Taal Lake, a known aquaculture site, and most fish cage operators and fish farmers implicate this to environmental and anthropogenic causes coming from milkfish and tilapia aquaculture effluents [32]. Vista et al., 2006 have attributed this water quality deterioration due to high stocking density and feed input from the fish farmers [33]. In addition, Primavera and co-workers (2007) suggested that chemical effluents in shrimp farming have been a concern and their possible impacts on the environment and human health, and will continue to be a subject for debate in the future for lack of knowledge in waste management $[41,68]$. The negative impacts of marine pollution on capture fisheries and aquaculture are becoming more apparent. Even the municipal fishery sub-sector, traditionally the main source of fish for domestic consumption, has declined steadily over the past several years $[69,70]$. Because most ponds used for shrimp culture are located in brackishwater, with mangroves converted for their use, mangrove forests have declined to only 120,000 ha while fish/shrimp culture ponds have increased to 232,000 ha [63]. The ecological services lost due to this mangrove conversion includes shoreline protection from tsunami, impacts of typhoons, impairment of the function of mangrove forests that act as carbon sink, destruction of nursery and spawning grounds of fish, shellfish and other aquatic life [64]. Along with mangrove decline is the ecosystem's susceptibility to climate change particularly on the rising sea level which can lead to higher risk to flooding, tsunamis, cyclones, and storm surges [65]. Fortunately, over the last few years, aquacultural activity in the Philippines was largely directed towards the production of milkfish, tilapia, seaweeds, mudcrabs and this has not reverted back to an aggressive shrimp culture, particularly for the giant tiger prawn Penaeus monodon, although perhaps $P$. vannamei is currently the culture of choice among shrimp farmers despite the challenges affecting shrimp farming.

Table 7. Environmental impacts of shrimp aquaculture*

\begin{tabular}{|c|c|c|}
\hline Environmental Inputs & Chemical used & Use/Effect \\
\hline \multirow[t]{4}{*}{ Pesticide } & $\begin{array}{l}\text { Saponin } \\
\text { (Teaseed Powder) }\end{array}$ & $\begin{array}{l}\text { Use during pond preparation (broadcast); } \\
\text { rearing phase (periodic); disease control } \\
\text { for 30-60 days; }\end{array}$ \\
\hline & Copper compounds & $\begin{array}{l}\text { Use during pond preparation (spray) and } \\
\text { rearing phase (until phytoplankton } \\
\text { bloom); }\end{array}$ \\
\hline & Potassium & Uced uring nond promantion (snroul) \\
\hline & & Use durıng pond preparation (spray) \\
\hline \multirow[t]{5}{*}{ Antibiotics } & Tetracycline & Every other day from stocking to harvest; \\
\hline & Rifampicin & Disease control, daily or until disappears; \\
\hline & Chloramphenicol & $\begin{array}{l}\text { Every other day from stocking to harvest; } \\
\text { Disease control, daily or until disappears. }\end{array}$ \\
\hline & Nitrofuran & $\begin{array}{l}\text { Every other day from } \mathrm{Z}_{1} \text { to harvest; dis- } \\
\text { ease control, } 3 \mathrm{~d} \text { (long bath). }\end{array}$ \\
\hline & Erythromycin & Disease control, $3 \mathrm{~d}$, (long bath) \\
\hline \multirow[t]{2}{*}{$\begin{array}{l}\text { Feeds } \\
\text { (Inorganic Fertilizer) }\end{array}$} & $\begin{array}{l}\text { 16-20-0 } \\
\text { (Mono-ammonium phos- } \\
\text { phate) }\end{array}$ & $\begin{array}{l}\text { Use during pond preparation (broadcast); } \\
\text { rearing phase (periodic, broadcast). }\end{array}$ \\
\hline & $\begin{array}{l}\text { 18-46-0 } \\
\text { (Diammonium phosphate) }\end{array}$ & Use during pond preparation (broadcast) \\
\hline
\end{tabular}


14-14-14

(NPK, complete fertilizer) Rearing phase (periodic, broadcast)

46-0-0 (Urea) Pond preparation, rearing phase

21-0-0

(Ammonium Sulfate)

Pond preparation, rearing phase

0-20-0 (Solophos)

Pond preparation, rearing phase

\begin{tabular}{|c|c|c|}
\hline \multirow[t]{5}{*}{ (Organic Fertilizer) } & Chicken manure & $\begin{array}{l}\text { Use during pond preparation, rearing } \\
\text { phase (tea bags) }\end{array}$ \\
\hline & Cow manure & Pond preparation, rearing phase (tea bags) \\
\hline & Carabao manure & Pond preparation, rearing phase (tea bags) \\
\hline & $\begin{array}{l}\text { VIMACA (chicken/pig ma- } \\
\text { nure) }\end{array}$ & Pond preparation (tea bags) \\
\hline & B-4 & Pond preparation (substitute for manure \\
\hline
\end{tabular}

Other Chemicals

(Soil and Water Treat-

ment) Lime

$\mathrm{pH}$ control in pond preparation. (3-7 days,

Dolomite

Pond preparation

Zeolite

Water quality control, disease control

Benzalkonium chloride

Water disinfectant

Oxytetracycline

Control of bacterial diseases

Teaseed cake

Predator control

*Source: Cruz-Lacierda, et al. [47].

\subsection{Socioeconomic impacts}

There have been several reports that aquaculture has been the cause of several problems such as economic and social impacts [23]. Aquaculture importation has been a worldwide practice and Penaeus vannamei has been imported for more than five decades, which already raised some concern as this adds to the cost of cultivation [72]. In addition, since $70 \%$ of most Filipinos live in coastal areas, their livelihoods are dependent on fishing, aquaculture, and the other auxiliary industries related to the fisheries, with 1.6 million of them being highly dependent for their livelihoods and protein requirement [73]. The marketing of seafood products in the Philippines is usually channeled to fish brokers with profit-making taking place within wholesalers, retailers, and brokers in the fisheries [74]. This causes the higher market price for aquatic products that puts them outside the range of urban poor consumers [75]. Black tiger prawn (Penaeus monodon) and Pacific Whiteleg (Penaeus vannamei) are highly traded species in the Philippines. Black tiger shrimp leads the highest production ranges from 45,000-50,000 mt annual production in 2008 to 2019, followed by the Pacific white shrimp with a production of nearly 2,000 $\mathrm{mt}$ in 2008 that gradually increased to $19,000 \mathrm{mt}$ in 2019 . They have contributed to our export earnings 
around U\$ 120 million in 2014, much higher than in 2013 that was U\$ 67.5 million [21]. While there is no arguing with the increase in its production, problems arise due to its socio-economic impacts. However, studies are limited to food security, equity, and development. More commonly, it has been stated that aquaculture which also applies to fish farming has been responsible for the marginalization of coastal communities and increased unemployment [23]. In contrast to this view, shrimp industry players, operators, feed companies, other stakeholders and politicians supporting the industry perceive that economic growth, especially about livelihood opportunities are created through the shrimp industry even in remote areas of the country [76]. The industry has been growing by $2.4 \%$ and produced an average of $65,000 \mathrm{mt}$ in the past 20 years. Shrimp farming activities contribute significantly both for the local and national economy of the Philippines and continues to be an export commodity for Japan, USA and South Korea and with high demand and price even in local and national markets [77]. Its production offers livelihood opportunities even to rural women and other value adding activities which provides employment and poverty alleviation for the country [78]. Women's roles are very important and strategic as they are considered to be key determinants for the food security and nutritional status of their households [79-80]. Moreover, empowered women help to improve the nutritional status of their children [81]. Clearly a balance is needed where both the location of largescale shrimp farms, even those of small-holder farmers must not necessarily displace existing artisanal fishers, gleaners, fry collectors, tourists, and other stakeholders that also utilize the mangrove and water resources of the area. Even if there are trade-offs, both livelihood and environmental concerns (water pollution, depletion of fry in the wild, spread of diseases, biodiversity impacts, aquatic invasions) should be both addressed as they go together in aquaculture $[19,33,82]$.

\subsection{Climate Change}

The Philippines ranks second in terms of global climate risk due to its vulnerability to climate change impacts [92,93], where it is projected to be a key reason for decline of the fisheries with huge economic costs [45]. Climate change affects the targeted population range and productivity, habitats, and fishery and aquaculture cost [94,95]. Changes in climatic variables facilitate the increased frequency of typhoons, and disease spread, causing physical damage to the farm's pond structure, deterioration of water quality and spread of disease and infection in shrimp ponds [94,96]. Issues and problems have arisen such as decrease in wild-caught shrimp fry and lack of hatcheries in strategic locations to supply shrimp farmers and increasing price of feeds are major concerns [94]. Few studies have analyzed the economic impacts of climate change on aquaculture and fisheries dealing with the national economy. The Philippines is projected to decrease by $9 \%$ its fisheries GDP with the climate change mitigation scenario and a decrease of $18 \%$ with the extreme scenario without mitigation [45]. As the aquaculture industry grapple with the impacts of climate change particularly heavy rains, cold months, draught, and extreme events, that inevitably impact the growth, survival and performance of cultured species, lowering their productivity and with possibility of higher disease transmission due to water quality deterioration, this has economic costs. The government should adopt further adaptation measures to prevent the catastrophic impacts of climate change and variabilities within the aquaculture sector [94]. This may include climate proofing of post-harvest facilities and increasing the number of its aquaculture hatcheries to avoid insufficient supplies. Enforcement of regulations in terms of number of cages, pens, cultured ponds and regulation of stocking density and proper land use planning, observance of aquaculture practices, proper coordination between local governments, the Bureau of Fisheries and Aquatic Resources (BFAR) for licensing and registration of fish cages, ponds and operators as well as the Department of Environment and Natural Resources (DENR) for regular water quality monitoring [32,33,97].

\section{Conclusion and Recommendation}


The intensification of the shrimp farms in the past has led to loss of mangrove areas, affected water quality, biodiversity, habitat and encouraged the proliferation of pathogens to the detriment of all shrimp farmers, operators and other stakeholders. The social ramifications included the displacement of subsistence fishers, gleaners, fry collectors and their market as mangrove fishing areas were converted for fishponds and other aquaculture uses. This has generated a suite of environmental and economic problems for the aquaculture sector in the Philippines as well as socioeconomic benefits. These are mainly damage to the mangrove forest and loss of biodiversity, increased soil salinity with serious loss of soil fertility, algal blooms, damage to coastlines due to water quality deterioration affecting its traditional uses for swimming or recreation as well as tourism purposes, displacement of subsistence fishers and gleaners as well as mangrove wood collectors, problems on land ownership and illegal occupation of protected landscapes and seascapes, loss of ecosystem services due to effluent impacts on phytoplankton diversity, fish diversity as well as destruction of seagrass and mangrove carbon sink, and aquatic invasions, antibiotic resistance and disease problems $[19,64,82-87]$. On the other hand, the positive impacts of shrimp aquaculture include, local employment of workers in the small-holder farms and largescale commercial farms, higher income for workers and operators improving their economic conditions, foreign direct investments in hatcheries, farms, post-harvest facilities as well as feed mills, involvement of women in the fish farms provide higher income, value adding activities, improvement of marketing, business diversification activities also occurred due to profit from shrimp farms e.g. lands, farms, vans were acquired as a result of profits, better educational and economic opportunities for the children of shrimp farmers $[78,82,88,89]$. The findings of this review show both the negative and positive impacts of shrimp farming. In order to address the current challenges of shrimp farming in the Philippines, the Bureau of Fisheries and Aquatic Resources (BFAR) have provided a blue print for strategies that will improve the sustainability of shrimp farming in the Philippines. These are to secure a pathogen and disease-free fry/seed supply and invest in propagation facilities e.g. broodstock, hatcheries, nurseries and laboratories; institutionalize good aquaculture practices and promote sustainable aquaculture; assure quality and traceable aquaculture inputs and ouputs, optimize operation of mariculture parks and ensure climate/disaster proof aquaculture sector [90]. Good aquaculture practices are now required for food safety and traceability for responsible seafood sourcing [91].

Thus, based on the above discussions and summary, regarding the lessons learnt from the environmental and socioeconomic impacts of shrimp farming, the following recommendations can be made about shrimp culture:

1. Considering the economic potential to uplift various households from poverty, a clearly planned coastal zone use and buffer areas should be delineated; shrimp pond operators should be educated, informed about land ownership, rental or leasing from the local government and the Department of Environment and Natural Resources (DENR) in cases that these culture sites are also located in protected areas.

2. Aquaculture operators whether small-holders or large-scale operators should be encouraged, taught how to organize themselves legally and registered so that they can avail of technical help from the local government as well as from Bureau of Fisheries and Aquatic Resources (BFAR).

3. Continuous efforts should be extended by the government to organized fish farmers especially in terms of disease monitoring and water quality monitoring to prevent disease spread and eventual economic loss.

4. Access to information, educational awareness should be spread in the comm unity organization as well as to other small-holder farmers for uniform implementa tion of government policies related to shrimp culture especially with regards to envi ronmental and disease monitoring.

5. Development and investments for hatcheries, nurseries and laboratories should be encouraged among private sector companies apart from government led initiatives. 
6. Shrimp farming should not be allowed on land where it would pose a great threat to cultivated crops, tourism or recreational areas; proper coastal zoning should be observed by all stakeholders; unplanned, no consultation aquaculture areas should be discouraged.

7. Where there is competition for water resources such as for crop cultivation and for aquaculture usage, priority is given to rice since it is a staple food. As much as possible, farmlands and shrimp cultivation areas should not be found in the same area due to possible effluent discharges and seepage.

8. In the shrimp farms areas proper provision of a network of water supply and drainage canals should be instituted with observation of better management practices. These should be properly or regularly monitored by the local government as well as BFAR.

9. Feeding, fertilizer usage and chemicals used should be applied only at recommended rates to avoid feed wastage and prevent chemical contamination.

10. Food safety and traceability practices and better farm management practices should be observed with corresponding sanctions and regular monitoring.

11. Strong network among research organizations, the local government, universi ties and colleges as well as NGOs through forums and extension services could im prove the knowledge, prevention of diseases and adoption of sustainable practices shrimp farmers will lead to better management practices.

Funding: The funding for this study was provided by DA-PRDP (Department of Agriculture-Philippine Rural Development Plan) through the project entitled: Vulnerability assessment of Pacific Whiteleg Shrimp (Penaeus vannamei) and associated species through the fisheries value-chain in Davao region.

Acknowledgement: This paper would not have been possible without the earlier assistance for literature review and data collection of our research assistants Nitcel Albarido, and Jenie Diuyan. We are also indebted to the earlier comments of the monitoring team from PRDP Mindanao branch.

\section{References}

1. FAO. The State of World Fisheries and Aquaculture 2020 Food and Agriculture Organization: Rome, Italy, 2020.

2. BFAR. Philippine Fisheries Profile 2019; Bureau of Fisheries and Aquatic Resources: Quezon City, Philippines, 2020; p. 76.

3. Islam, M.; Yasmin, R. Impact of aquaculture and contemporary environmental issues in Bangladesh. Int. J. Fish. Aquat. Stud. 2017, 5, 100-107.

4. Joffre, O.M.; Bosma, R.H. Typology of shrimp farming in Bac Lieu Province, Mekong Delta, using multivariate statistics. Agriculture, Ecosystems \& Environment 2009, 132, 153-159, doi:doi:10.1016/j.agee.2009.03.010

5. Henriksson, P.J.G.; Banks, L.K.; Suri, S.K.; Pratiwi, T.Y.; Fatan, N.A.; Troell, M. Indonesian aquaculture futures -identifying interventions for reducing environmental impacts. Environmental Research Letters 2019, 14, 124062, doi:10.1088/17489326/ab4b79.

6. Guerrero, R.D. Farmed tilapia production in the Philippines is declining: What has happened and what can be done. Philippine Journal of Science 2019, 148, XI-XV.

7. Miao, W.; Mohan, C.V.; Ellis, W.; Brian, D. Adoption of Aquaculture Assessment Tools for Improving the Planning and Management of Aquaculture in Asia and the Pacific; FAO Regional Office for Asia and the Pacific, Bangkok, Thailand: Bangkok, Thailand, 2013; p. 136.

8. Largo, D.B.; Diola, A.G.; Marababol, M.S. Development of an integrated multi-trophic aquaculture (IMTA) system for tropical marine species in southern cebu, Central Philippines. Aquaculture Reports 2016, 3, 67-76.

9. Walker, P.J.; Winton, J.R. Emerging viral diseases of fish and shrimp. Vet Res 2010, 41, 51, doi:10.1051/vetres/2010022.

10. Béné, C.; Barange, M.; Subasinghe, R.; Pinstrup-Andersen, P.; Merino, G.; Hemre, G.-I.; Williams, M. Feeding 9 billion by 2050 - Putting fish back on the menu. Food Sec. 2015, 14, doi:DOI 10.1007/s12571-015-0427-z.

11. Diana, J.S. Aquaculture Production and Biodiversity Conservation. BioScience 2009, 59, 27, doi:http://dx.doi.org/10.1525/bio.2009.59.1.7.

12. Béné, C.; Arthur, R.; Norbury, H.; Allison, E.H.; Beveridge, M.; Bush, S.; Campling, L.; Leschen, W.; Little, D.; Squires, D.; et al. Contribution of Fisheries and Aquaculture to Food Security and Poverty Reduction: Assessing the Current Evidence. World Development 2016, 79, 177-196, doi:http://dx.doi.org/10.1016/j.worlddev.2015.11.007.

13. FAO. The State of World Fisheries and Aquaculture (SOFIA); Food and Agriculture Organization: Rome, Italy, 2007.

14. Vo, L.T.T. Quality management in shrimp supply chain in the Mekong Delta, Vietnam: problems and measures; Center for ASEAN studies: Antwerp, Belgium, 2003; p. 28.

15. Martinez-Cordova, L.R.; Martinez-Porchas, M. Polyculture of Pacific white shrimp, Litopenaeus vannamei, giant oyster, Crassostrea gigas and black clam, Chione fluctifraga in ponds in Sonora, Mexico. Aquaculture 2006, 258, 321-326. 
16. Cuvin-Aralar, M.L.A.; Lazartigue, A.G.; Aralar, E.V. Cage culture of the Pacific white shrimp Litopenaeus vannamei (Boone, 1931) at different stocking densities in a shallow eutrophic lake. Aquaculture Research 2009, 40, 181-187.

17. Rosario, W.R.; Lopez, N.A. Status of P. Vannamei Aquaculture in the Philippines; SEAFDEC Aquaculture Department: Tigbauan, Iloilo, Philippines, 2005; pp. 62-68.

18. Shinn, A.P.; Pratoomyot, J.; Griffiths, D.; Trong, T.Q.; Vu, N.T.; Jiravanichpaisal, P.; Briggs, M. Asian Shrimp Production and the Economic Costs of Disease. Asian Fisheries Science 2018, 31S, 29-58.

19. Primavera, J.H. Overcoming the impacts of aquaculture on the coastal zone. Ocean and Coastal Management 2006, 49, 531-545, doi:10.1016/j.ocecoaman.2006.06.018.

20. PSA. Fisheries Situationer of the Philippines; Philippine Statistics Authority: Quezon City, 2020; p. 321.

21. Vergel, J.C.V. Current Trends in the Philippines' Shrimp Aquaculture Industry: A Booming Blue Economy in the Pacific Oceanography and Fisheries Open Access Journal 2017, 5, 555668, doi:DOI: 10.19080/OFOAJ.2017.05.555668.

22. Tendencia, E.A.; Bosma, R.H.; Verdegem, M.C.J.; Verreth, J.A.J. The potential effect of greenwater technology on water quality in the pond culture of Penaeus monodon Fabricius. Aquaculture Research 2013, 2013, 1-13.

23. Primavera, J.H. Socioeconomic impacts of shrimp culture. Aquaculture Research 1997, 28, 815-827.

24. Primavera, J.H. A critical review of shrimp pond culture in the Philippines. Rev Fish Sci 1993, 1, 151-201, doi:doi:10.1080/10641269309388539.

25. PhilStat. Fisheries Statistics of the Philippines 2014-2016; Philippine Statistics Authority: Quezon City, Philippines, 2017; pp. 484523.

26. Pudadera, B.J.; Lim, C. Evaluation of milkfish (Chanos chanos Forskal) and prawn (Penaeus monodon Fabricius) in polyculture systems. Fisheries Research Journal of the Philippines 1980, 7, 51-59.

27. Eldani, A.; Primavera, J.H. Effect of different stocking combinations on growth, production and survival of milkfish (Chanos chanos) and prawn (Penaeus monodon) in polyculture in brackishwater. Aquaculture 1981, 23, 59-72.

28. Flegel, T.W.; Lightner, D.V.; Lo, C.F.; Owens, L. Shrimp disease control: past, present and future. In Proceedings of the Diseases in Asian Aquaculture Manila, Philippines, 2008; pp. 355-378.

29. Tendencia, E.A.; dela Peña, M. Investigation of some components of the greenwater system which makes it effective in the initial control of luminous bacteria. Aquaculture 2003, 218, 115-119, doi:https://doi.org/10.1016/S0044-8486(02)00524-0.

30. Holmer, M., Marba, N., Terrados, J., Duarte, C.M., Fortes, M.D., 2002. Impacts of milkfish (Chanos chanos) aquaculture on carbon and nutrient fluxes in the Bolinao area, Philippines. Mar Poll Bull 44, 685-696.

31. Azanza, R., Baula, I., Fukuyo, Y., 2006. Seasonal changes in phytoplankton composition in an extensive fish culture area in Bolinao, Pangasinan Philippines. Coastal Marine Science 30, 85-87.

32. Macandog, D.M., de la Cruz, C.P.P., Edrial, J.D., Reblora, M.A., Pabico, J.P., Salvacion, A.R., Marquez, J., T.L.,, Macandog, P.B.M., Perez, D.K.B., 2014. Eliciting Local Ecological Knowledge and Community Perception on Fishkill in Taal Lake through Participatory Approaches. Journal of Environmental Science and Management 17, 1-16.

33. Vista, A., Norris, P., Lupi, F., Bernsten, R., 2006. Nutrient loading and efficiency of tilapia cage culture in Taal Lake, Philippines. $89,48-57$

34. Jaspe, C.J.; Caipang, C.M.A.; Elle, B.J.G. Polyculture of white shrimp, Litopenaeus vannamei and milkfish, Chanos chanos as a strategy for efficient utilization of natural food production in ponds. ABAH Bioflux 2011, 3, 96-104.

35. Moher, D.; Liberati, A.; Tetzlaff, J.; Altman, D.G. Preferred Reporting Items for Systematic Reviews and Meta-Analyses: The PRISMA Statement. PLoS Med 2009, 6, e1000097, doi:doi:10.1371/journal.pmed.1000097.

36. Alam, G.M.M., Sarker, M.N.I., Gatto, M., Bhandari, H., Naziri, D., 2022. Impacts of COVID-19 on the Fisheries and Aquaculture Sector in Developing Countries and Ways Forward. Sustainability 14, 1071.

37. Liu, J.-M.; Borazon, E.Q.; Muñoz, K.E. Critical problems associated with climate change: a systematic review and meta-analysis of Philippine fisheries research. Environmental Science and Pollution Research, 2021, doi:https://doi.org/10.1007/s11356-021-157126.

38. Li, T.; Hua, F.; Dan, S.; Zhong, Y.; Levey, C.; Song, Y. Reporting quality of systematic review abstracts in operative dentistry: an assessment using the PRISMA for Abstracts guidelines. J Dent 2020, 102, 103471.

39. Sharma, S.; Oremus, M. PRISMA and AMSTAR show systematic reviews on health literacy and cancer screening are of good quality. J Clin Epidemiol 2018, 99, 123-131.

40. van Eck, N.J.; Waltman, L. Software survey: VOSviewer, a computer program for bibliometric mapping. Scientometrics 2010, 84, 523-538, doi:10.1007/s11192-009-0146-3.

41. Snilstveit, B., Oliver, S., Vojtkova, M., 2012. Narrative approaches to systematic review and synthesis of evidence for international development policy and practice. Journal of Development Effectiveness 4, 409-429.

42. Schick-Makaroff, K., MacDonald, M., Plummer, M., Burgess, J., Neander, W., 2016. What synthesis methodology should I use? A review and analysis of approaches to research synthesis. AIMS Public Health 3, 172.

43. Ashton, E.C. The impact of shrimp farming on mangrove ecosystems: perspectives in Agriculture, Veterinary Science, Nutrition and Natural Resources CAB Reviews 2008, 3, 1-12, doi:10.1079/PAVSNNR20083003.

44. Primavera, J.H.; Altamirano, J.P.; Lebata, M.J.H.L.; delos Reyes Jr., A.A.; Pitogo, C.L. Mangroves and shrimp pond culture effluents in Aklan, Panay is., Central Philippines. B Mar Sci 2007, 80, 795-804.

45. Suh, D.; Pomeroy, R. Projected Economic Impact of Climate Change on Marine Capture Fisheries in the Philippines. Frontiers in Marine Science 2020, 7, 232, doi:doi: 10.3389/fmars.2020.00232. 
46. Macusi, E.D.; Abreo, N.A.S.; Cuenca, G.C.; Ranara, C.T.B.; Cardona, L.T.; Andam, M.B.; Guanzon, G.C.; Katikiro, R.E.; Deepananda, K.H.M.A. The potential impacts of climate change on freshwater fish, fish culture and fishing communities Journal of Nature Studies 2015, 14, 14-31.

47. Cruz-Lacierda, E.; Corre, V.; Yamamoto, A.; Koyama, J.; Matsuoka, T. Current Status on the Use of Chemicals and Biological Products and Health Management Practices in Aquaculture Farms in the Philippines. Mem. Fac. Fish. Kagoshima Univ. 2008, 57, 37-45.

48. de la Peña, L.D.; Lavilla-Pitogo, C.R.; Villar, C.B.R.; Paner, M.G.; Sombito, C.D.; Capulos, G.C. Prevalence of white spot syndrome virus (WSSV) in wild shrimp Penaeus monodon in the Philippines. Dis Aquat Organ 2007, 77, 175-179, doi:DOI: 10.3354/dao01834.

49. Lavilla-Pitogo, C.R.; de la Pena, L.D. Bacterial Disease in Shrimp (Penaeus monodon) culture in the Philippines. Fish Pathol 1998, 33, 405-411.

50. Baticaldos, M.C.L.; Cruz-Lacierda, E.R.; de la Cruz, M.C.; Duremdez-Fernandez, R.C.; Gacutan, R.Q.; Lavilla-Pitogo, C.R.; LioPo, G.D. Disease of Penaeid Shrimps in the Philippines; Aquaculture Department, Southeast Asian Fisheries Development Center: Tigbauan, Iloilo, Philippines, 1990; pp. 1-46.

51. Karunasagar, I.; Ababouch, L. Shrimp viral diseases, import risk assessment and international trade. Indian J Virology 2012, 23, 141-148.

52. Momoyama, K.; Hiraoka, M.; Nakano, H.; Koube, H.; Inouye, K.; Oseko, N. Mass mortalities of cultured Kuruma shrimp, Penaeus japonicus, in Japan in 1993 Fish Pathology 1994, 29, 141-158.

53. Belak, J.; Dhar, A.K.; Primavera, J.H. Prevalence of viral diseases (IHHNV and WSSV) in Penaeus monodon from the Philippines and its association with mangrove status and shrimp culture systems In Proceedings of the Proceedings of the Aquaculture and Conservation of Marine Shrimp Biodiversity Symposium, North Grafton, Massachusets, 1999.

54. Tendencia, E.A.; Bosma, R.H.; Verreth, J.A.J. White spot syndrome virus (WSSV) risk factors associated with shrimp farming practices in polyculture and monoculture farms in the Philippines. Aquaculture 2011, 311, 87e93.

55. Briggs, M.; Funge-Smith, S.; Subasinghe, R.; Phillips, M. Introductions and movement of Penaeus vannamei and Penaeus stylirostris in Asia and the Pacific; Bangkok Food and Agriculture Organization of the United Nations: Bangkok, Thailand, $2004 ;$ p. 88.

56. Vergel, J.C.V.; Cabawatan, L.D.P.; Madrona, V.A.C.; Rosario, A.F.T.; Sta. Ana, J.M.B.; Tare, M.V.R.; Maningas, M.B.B. Detection of Taura Syndrome Virus (TSV) in Litopenaeus vannamei in the Philippines. The Philippines Journal of Fisheries 2019, 26, 8-14.

57. Moriarty, D.J.W. Disease Control in Shrimp Aquaculture with Probiotic Bacteria. In Proceedings of the Proceedings of the 8th International Symposium on Microbial Ecology, Halifax, Canada, 1999; pp. 1-7.

58. Lavilla-Pitogo, C.R.; Lio-Po, G.D.; Cruz-Lacierda, E.R.; Alapide-Tendencia, E.V.; de la Peña, L.D. Diseases of penaeid shrimps in the Philippines; Aquaculture Department, Southeast Asian Fisheries Development Center (SEAFDEC): Tigbauan, Iloilo, 2000.

59. Orosco, F.L.; Lluisma, A.O. Prevalence, diversity and co-occurrence of the white spot syndrome virus, monodon baculovirus and Penaeus stylirostris densovirus in wild populations of Penaeus monodon in the Philippines. Dis Aquat Organ 2017, 125(3):. PMID: 28792418., 199-206, doi:doi: 10.3354/dao03150.

60. Rajendran, K.V.; Makesh, M.; Karunasagar, I. Monodon baculovirus of shrimp. Indian J Virol 2012, 23, 149-160, doi:10.1007/s13337-012-0086-z.

61. Baticados, M.C.L.; Cruz-Lacierda, E.R.; De la Cruz, M.C.; Duremdez-Fernandez, R.C.; Gacutan, R.Q.; Lavilla-Pitogo, C.R.; LioPo, G.D. Diseases of penaeid shrimps in the Philippines. Aquaculture Department, Southeast Asian Fisheries Development Center (SEAFDEC): Tigbauan, Iloilo, Philippines, 1990.

62. Flegel, T.W. Detection of major penaeid shrimp viruses in Asia, a historical perspective with emphasis on Thailand. Aquaculture 2006, 258, 1-33.

63. De la Peña, L.D. Transboundary shrimp viral diseases with emphasis on white spot syndrome virus (WSSV) and taura syndrome virus (TSV); Aquaculture Department, SEAFDEC: Tigbauan, Iloilo, Philippines, 2004; pp. 67-69.

64. Lee, S.Y., Primavera, J.H., Dahdouh-Guebas, F., Mckee, K., Bosire, J.O., Cannicci, S., Diele, K., Fromard, F., Koedam, N., Marchand, C., Mendelssohn, I., Mukherjee, N., Record, S., 2014. Ecological role and services of tropical mangrove ecosystems: A reassessment. Glob. Ecol. Biogeogr. 23, 726-743.

65. Cuenca, G.C., Macusi, E.D., Abreo, N.A.S., Ranara, C.T.B., Andam, M.B., Cardona, L.T., Guanzon, G.C., 2015. Mangrove Ecosystems and Associated Fauna with Special Reference to Mangrove Crabs in the Philippines: A Review. IAMURE International Journal of Ecology and Conservation 15, 60-110.

66. Baticados, M.C.L.; Lavilla-Pitogo, C.R.; Cruz-Lacierda, E.R.; de la Peña, L.D.; Suñaz, N.A. Studies on the chemical control of luminous bacteria Vibrio harveyi and V. splendidus isolated from diseased Penaeus monodon larvae and rearing water. Dis Aquat Organ 1990, 9, 133-139.

67. Primavera, J.H.; Esteban, J. A review of mangrove rehabilitation in the Philippines: successes, failures and future prospects. Wetlands Ecology and Management 2008, 16, 345-358, doi:10.1007/s11273-008-9101-y.

68. Subasinghe, R.P.; Network of Aquaculture Centres in Asia-Pacific.; Food and Agriculture Organization of the United Nations. Aquaculture in the third millennium; NACA/FAO: Bangkok, 2001; p. 471 p.

69. Muallil, R.N.; Mamauag, S.S.; Cababaro, J.T.; Arceo, H.O.; Aliño, P.M. Catch trends in Philippine small-scale fisheries over the last five decades: The fishers' perspectives. Marine Policy 2014, 47, 110-117, doi:http://dx.doi.org/10.1016/j.marpol.2014.02.008.

70. Macusi, E.D.; Liguez, A.K.O.; Macusi, E.S.; Digal, L.N. Factors influencing catch and support for the implementation of the closed fishing season in Davao Gulf, Philippines. Marine Policy 2021, 104578, doi:https://doi.org/10.1016/j.marpol.2021.104578.

71. Cruz-Lacierda, E.R.; de la Peña, L.D.; Lumanlan-Mayo, S.C. The Use of Chemicals in Aquaculture in the Philippines. In Proceedings of the Use of Chemicals in Aquaculture in Asia, Tigbauan, Iloilo, Philippines, 1996; pp. 155-184. 
72. Alejos, M.S.; Serrano, A.E.; Jumah, Y.U.; Dela Calzada, R.; Ranara, C.T.B.; Fernandez, J.C. Ecological and social impacts of aquacultural introduction to Philippines waters of Pacific whiteleg shrimp Penaeus vannamei. In Spatial Variability in Environmental Science - Patterns, Processes, and Analyses; 2020

73. Macusi, E.D.; Macusi, E.S.; Jimenez, L.A.; Catam-isan, J.P. Climate change vulnerability and perceived impacts on small-scale fisheries in eastern Mindanao. Ocean $\mathcal{E}$ Coastal Management 2020, 189, 105143, doi:https://doi.org/10.1016/j.ocecoaman.2020.105143.

74. Drury O'Neill, E.; Crona, B.; Ferrer, A.J.G.; Pomeroy, R.; Jiddawi, N.S. Who benefits from seafood trade? A comparison of social and market structures in small-scale fisheries. Ecol Soc 2018, 23.

75. Olalo, C. Production, accessibility and consumption patterns of aquaculture products in the Philippines; Food and Agriculture Organization: Rome, Italy, 2001.

76. Miraflor, M.B., 2021. PH shrimp production to remain stagnant, Manila Bulletin. Herminio Coloma Jr., Manila, Philippines.

77. BFAR, 2020. Philippine Fisheries Profile 2019. Bureau of Fisheries and Aquatic Resources, Quezon City, Philippines, p. 76.

78. Bassig, R.A., Obinque, A.V., Nebres, V.T., Delos Santos, V.H., Peralta, D.M., Madrid, A.J.J., 2022. Utilization of Shrimp Head Wastes into Powder Form as Raw Material for Value-Added Products. The Philippine Journal of Fisheries 28, 181-190.

79. Smith, L.C., Ramakrishnan, U., Ndiaye, A., Haddad, L., Martorell, R., 2003. The importance of women's status for child nutrition in developing countries. International Food Policy Research Institute (IFPRI), Washington, DC, USA, p. 164.

80. Wandel, M., Holmboe-Ottesen, G., 1992. Women's work in agriculture and child nutrition in Tanzania. J Trop Pediatr 38, 252255.

81. Cunningham, K., Ploubidis, G.B., Menon, P., Ruel, M., Kadiyala, S., Uauy, R., Ferguson, E., 2015. Women's empowerment in agriculture and child nutritional status in rural Nepal. Public Health Nutr. 18, 3134-3145.

82. Islam, M.S., Islam, M.S., Wahab, M.A., Miah, A.A., Mustafa Kamal, A.H.M., 2003. Impacts of Shrimp Farming on the Socioeconomic and Environmental Conditions in the Coastal Regions of Bangladesh. Pakistan Journal of Biological Sciences 6, 20582067.

83. Hossain, A., Habibullah-Al-Mamun, M., Nagano, I., Masunaga, S., Kitazawa, D., Matsuda, K., 2022. Antibiotics, antibiotic-resistant bacteria, and resistance genes in aquaculture: risks, current concern, and future thinking. Environ Sci Pollut R 29, 1105411075.

84. San Diego-McGlone, M.L., Azanza, R.V., Villanoy, C.L., Jacinto, G.S., 2008. Eutrophic waters, algal bloom and fish kill in fish farming areas in Bolinao, Pangasinan, Philippines. Marine Pollution Bulletin 57, 295-301.

85. Song, A.M., Dressler, W.H., Satizábal, P., Fabinyi, M., 2021. From conversion to conservation to carbon: The changing policy discourse on mangrove governance and use in the Philippines. Journal of Rural Studies 82, 184-195.

86. Bagarinao, T.U., 2021. Biodiversity in Mangrove-derived Aquaculture Ponds in Dumangas, Iloilo, Philippines. Philippine Journal of Science 150, 153-169.

87. Edwards, P., 2015. Aquaculture environment interactions: past, present and likely future. Aquaculture 447, 2-14

88. Torell, E., Castro, J., Lazarte, A., Bilecki, D., 2021. Analysis of Gender Roles in Philippine Fishing Communities. Journal of International Development 33, 233-255.

89. Ferrer, A.J., Francisco, H.A., Carmelita, B.M., Hopanda, J., Predo, C., 2017. Gender Differences in Participation, Roles, and Attitude towards Mariculture Operation: A Case Study in the Philippines. Asian Fisheries Science 30.

90. BFAR, 2016. Comprehensive National Fisheries Industry Development Plan (CNFIDP) Medium Term Plan 2016-2020 Department of Agriculture-Bureau of Fisheries and Aquatic Resources (DA-BFAR), Quezon City, Philippines.

91. Kusumawati, R., Bush, S.R., 2015. Co-producing Better Management Practice standards for shrimp aquaculture in Indonesia. https://doi.org/10.1186/s40152-015-0039-4. Maritime Studies 14, 21.

92. Monnier, L.; Gascuel, D.; Alava, J.J.; Barragán, M.J.; Gaibor, N.; Hollander, F.A.; Kanstinger, P.; Niedermueller, S.; Ramírez, J.; Cheung, W.W.L. Small-scale fisheries in a warming ocean: exploring adaptation to climate change; WWF Germany, 2020.

93. Eckstein, D.; Künzel, V.; Schäfer, L.; Winges, W. Global Climate Risk Index 2020: Who Suffers Most from Extreme Weather Events? Weather-Related Loss Events in 2018 and 1999 to 2018 Bonn, Germany, 2020; p. 44.

94. Macusi, E.D.; Geronimo, R.C.; Santos, M.D. Vulnerability drivers for small pelagics and milkfish aquaculture value chain determined through online participatory approach. Marine Policy 2021, 133, 104710, doi:https://doi.org/10.1016/j.marpol.2021.104710.

95. Islam, A.M.; Akber, M.A.; Ahmed, M.; Rahman, M.M.; Rahman, M.R. Climate change adaptations of shrimp farmers: a case study from southwest coastal Bangladesh. Climate and Development 2018, 11, 459-468, doi:https://doi.org/10.1080/17565529.2018.1442807.

96. Macusi, E.D.; Kezia L. Camaso, K.L.; Barboza, A.; Macusi, E.R. Perceived vulnerability and climate change impacts on smallscale fisheries in Davao gulf, Philippines. Frontiers in Marine Science 2021, 8, 597385, doi:doi: 10.3389/fmars.2021.597385.

97. Jacinto, G.S., 2011. Fish Kill in the Philippines - Déjà Vu. Science Diliman 23 1-3. 